\title{
Impact of EGR control at in-cylinder pressure and ecological properties of CI off-road vehicle engine
}

\begin{abstract}
An attempt has been made to clarify the effect of wide-ranging control of the exhaust gas recirculation system on the cylinder pressure and ecological engine performance. This publication contains the results of tests performed on the CI (compression ignition) engine of the off-road vehicle mounted on the test bench. The study was based on advanced EGR control with a proportional valve and a very efficient exhaust gases cooling system. Analysis of the test results is based on the cylinder pressure and the concentration of $N O_{x}$ and $P M$ components at exhaust gases. The study included the influence of the exhaust gas recirculation system control on parameters such as differential pressure, $M B F$, and relative $N O_{x}$ and PM emissions. As demonstrated by the analysis conducted, the EGR valve control method and the exhaust gas cooling intensity significantly affect the cylinder pressure and its ecological performance.
\end{abstract}

Key words: exhaust gas recirculation, in-cylinder pressure, mass fraction burning, differential pressure, $N O_{x}$, particulate matter PM

\section{Introdution}

Continuous increase in emissions requirements for internal combustion engines due to increasingly stringent emission standards for both road and off-road vehicles results in the need to improve methods to reduce emissions of nitrogen oxides, carbon monoxide, hydrocarbons, particulate matter and other compounds in the exhaust gases. In the case of non-road vehicles in the latest standards, there is a tendency for significant exacerbation of mainly $\mathrm{NO}_{\mathrm{x}}$ and particulate matter (PM) emissions. Among the many methods used to reduce the emission of harmful substances, the methods used are in-cylinder and after treatment methods. It is of great importance to reduce emissions already at the stage of the generation of harmful exhaust gases, which can reduce or simplify the equipment belonging to the after treatment systems of reducing harmful substances in exhaust gases. Mechanisms for the formation of both $\mathrm{NO}_{\mathrm{x}}$ and PM are related to processes occurring in the cylinder during the combustion process, so it is important to monitor them. One of the possibilities of evaluating the combustion process is to observe the pressure in the cylinder and then its thorough analysis. As a result, a number of engine performance indicators can be obtained to evaluate the course of the combustion process. In-depth analysis of the combustion process allows you to indicate areas of the engine where improvement of engine performance can be achieve by adjusting the control parameters to take a compromise between some of them, such as engine efficiency, engine performance.

Control of the internal combustion engine should be based on analysis of the combustion process occurring in the cylinder, so it is important to take into account a number of parameters resulting from the analysis of the incylinder pressure $[1,13,17,20]$. Taking into account the increase curve of in-cylinder pressure, pressure peak and heat release, as well as other parameters, in controlling the combustion process in the cylinder can lead to improvement of combustion process. The expected effect of such control is to improve both ecological and economical engine properties.
In addition, it should be noted that the emission of particular harmful substances may be interdependent, which may lead to a slight reduction in emissions of one harmful substance to a significant increase in other. Commonly used incylinder limitation of harmful exhaust gas compounds are advanced fuel injection control with multiphase fuel injection and also exhaust gas recirculation. Huge influence on the pressure of the cylinder, and consequently exhaust emission has an injection control [4-6]. Also, the method of controlling the amount of exhaust gas recirculation, the cooling level of the recirculated exhaust gas is important not only for the ecological properties of the engine [2, 3, 7$10,12,19]$, but it also affects the performance indicators such as power or torque. Other aspects of engine performance, such as irregularity of engine speed [16], noise or fuel consumption [11] could be also taken into account during control process. Monitoring of the in-cylinder pressure and their analyzing allows, among other things, such control of the exhaust gas recirculation system to obtain the most favorable values of the individual engine performance indicators $[1,13,15,17,20]$. Information on the combustion process can be used to control both fuel injection and exhaust gas recirculation system.

\section{Research methodology}

\subsection{Research object}

In order to investigate selected engine operating indexes, the Z1505 engine used in agricultural tractors (Fig. 1) was mounted on a test bench. The tested research object has a maximum power of $92 \mathrm{~kW}$ at $2200 \mathrm{rpm}$. The engine is powered by diesel fuel by means of a prototype multiphase injection pump and equipped with a turbocharger with a relief valve and intake air cooler. The tested engine is also equipped with cooled EGR system. In addition, an advanced exhaust gas recirculation system, consisting of a gas-liquid heat exchanger, a proportional EGR valve and a feedback system, incorporates an integrated $\mathrm{NO}_{\mathrm{x}} / \mathrm{O}_{2}$ sensor. The test stand is equipped with an AVL pressure sensor located in one of the test engine cylinders. 


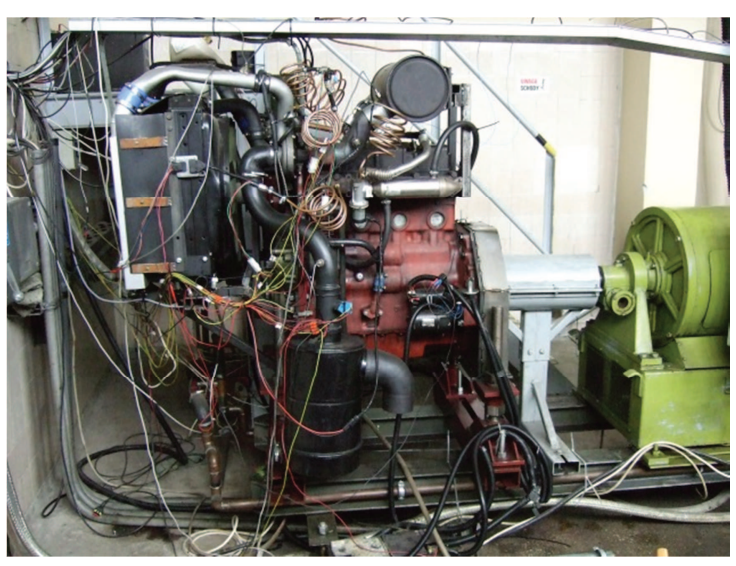

Fig. 1. Research engine mounted at test bench

Comparative studies have also been conducted for standard and modified (advanced) exhaust cooling systems. The modification of the cooling system was to increase the cooling level of the exhaust gas by using a refrigerant flowing through a gas-liquid heat exchanger with an inlet temperature of about $50 \mathrm{~K}$ lower than in the standard system during normal engine operation.

\subsection{Research scope}

Several engine cycles were registered, followed by averaging the pressure waveform, which, in view of some irregularities in subsequent cycles, minimizes the risk of selection for comparing accidental cylinder pressure. Determining the effect of exhaust gas recirculation on the cylinder pressure during engine operation there were required to select and averaged a series of stationary test cycles at selected speeds and torque loads.

Table 1. Main operating points of the tested engine - research scope

\begin{tabular}{|c|c|c|}
\hline $\begin{array}{c}\text { Group of } \\
\text { points }\end{array}$ & $\begin{array}{c}\text { Engine rotational speed } \\
\text { rpm }\end{array}$ & Engine load, Nm \\
\hline 1 & 800 & $0-100$ \\
\hline 2 & 900 & $0-190$ \\
\hline 3 & 1000 & $0-190$ \\
\hline 4 & 1200 & $0-190$ \\
\hline 5 & 1400 & $0-190$ \\
\hline 6 & 1600 & $0-190$ \\
\hline 7 & 1800 & $0-190$ \\
\hline 8 & 2000 & $0-190$ \\
\hline 9 & 2200 & $0-190$ \\
\hline
\end{tabular}

Table 2. Operating points of EGR valve

\begin{tabular}{|c|c|c|}
\hline No & $\begin{array}{c}\text { EGR valve opening posi- } \\
\text { tion, } \mathrm{mm}\end{array}$ & $\begin{array}{c}\text { EGR valve relative opening } \\
\text { level, } \%\end{array}$ \\
\hline 1 & 0 & 0 \\
\hline 2 & 0.199 & 3 \\
\hline 3 & 0.398 & 6 \\
\hline 4 & 0.598 & 9 \\
\hline 5 & 0.747 & 11 \\
\hline 6 & 0.896 & 13 \\
\hline 7 & 1.444 & 29 \\
\hline 8 & 2.490 & 50 \\
\hline 9 & 4.98 & 100 \\
\hline
\end{tabular}

The tests were conducted for a full range of rotational speeds (800-2200 rpm) and torque loads ranging from 0 $190 \mathrm{Nm}$ (Table 1) and at different EGR valve opening level (Table 2).

\section{Research problem}

The main research problem is to clarify the effect of wide-ranging control of the exhaust gas recirculation system on the cylinder pressure and ecological engine performance.

The in-cylinder pressure profile contains a lot of information about the combustion process. The comparison of the in-cylinder pressure waveform without the fuel injection (motored in-cylinder pressure) with the pressure wave resulting from the initiated combustion process (Fig. 2) allows to determine the course of the differential pressure.

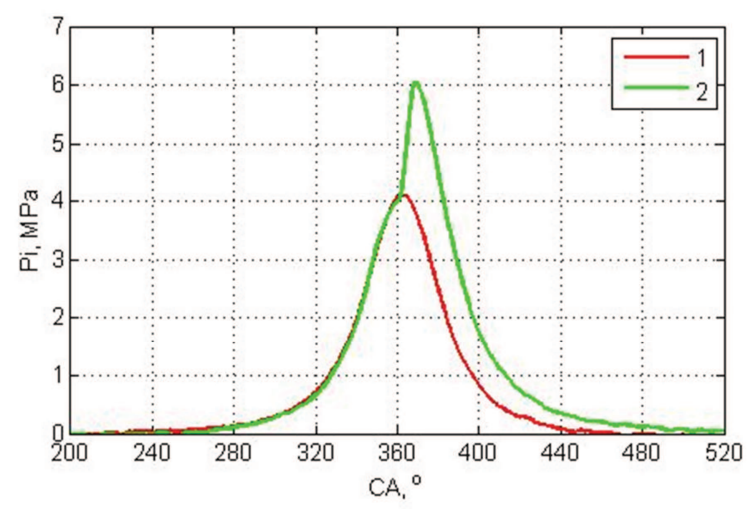

Fig. 2. In-cylinder pressure course at engine rotational speed $1000 \mathrm{rpm}$ (1 - motored pressure, 2 - in-cylinder pressure at $190 \mathrm{Nm}$ load)

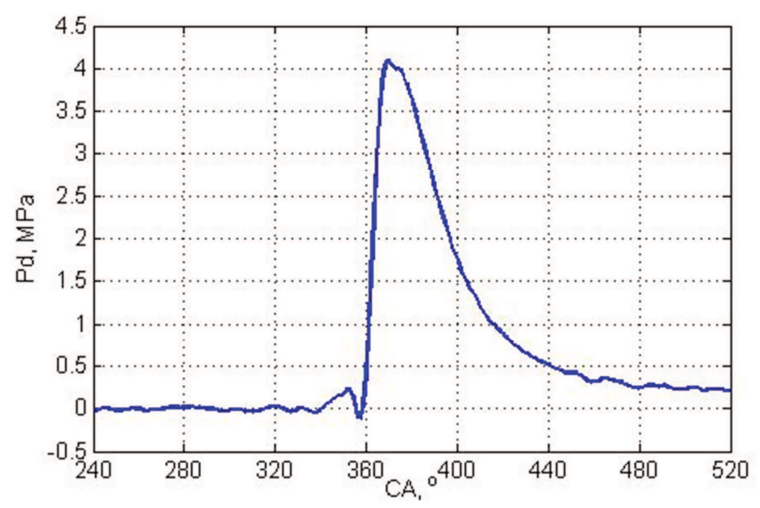

Fig. 3. Differential pressure at 100\% EGR valve open (1000 rpm, $190 \mathrm{Nm}$ )

Differential pressure is difference between motored incylinder pressure and in-cylinder pressure during combustion. Its variation allows for an overall assessment of the course of the combustion process, including, among other things, the rate of in-cylinder pressure increase resulting from fuel combustion, the occurrence of the maximum differential pressure ect.

$$
\mathrm{p}_{\mathrm{d}(\mathrm{i})}=\mathrm{p}_{\mathrm{comb}(\mathrm{i})}-\mathrm{p}_{\text {motored }(\mathrm{i})}
$$

were: $p_{d(i)}$ - differential pressure at $\mathrm{i}$-th interval, $\mathrm{p}_{\text {comb(i) }}-$ combustion pressure at $\mathrm{i}$-th interval, $\mathrm{p}_{\operatorname{motored}(\mathrm{i})}-$ motored pressure at $\mathrm{i}$-th interval.

Mass fraction burned (MFB) is one of the important thermo dynamical engine indexes. In each individual engine cycle is a normalized quantity with a scale of 0 to 1 , describing the process of chemical energy release as a function of crank angle $[14,18]$. The determination of MBF is 
based on burn rate analysis an there are many methods to evaluated it, but a procedure described by Rassweiler and Withrow [14] is a base method widely used because of its simplicity:

$$
M F B=\frac{\mathrm{m}_{\mathrm{b}}(\mathrm{i})}{\sum_{0}^{\mathrm{N}} \mathrm{m}_{\mathrm{b}}(\mathrm{i})}=\frac{\sum_{0}^{\mathrm{i}} \Delta \mathrm{p}_{\mathrm{i}}}{\sum_{0}^{\mathrm{N}} \Delta \mathrm{p}_{\mathrm{i}}}
$$

were: $\mathrm{m}_{\mathrm{b}}$ - mass burning, $\mathrm{i}$ - number of analysis interval, $\Delta \mathrm{p}_{\mathrm{i}}$ - pressure rise at i-th interval, 0 - start of combustion, $\mathrm{N}$ - number of interval between start and end of combustion.

It can be assumed that in the range of the crankshaft angles in which the combustion process occurs takes place equality:

$$
\Delta \mathrm{p}_{\mathrm{i}}=\mathrm{p}_{\mathrm{d}(\mathrm{i})}
$$

From the work of many researchers it is clear that the use of the cylinder pressure analysis to control the combustion process in the engine allows many parameters to be improved. Thanks to the use of the pressure waveform analysis, both the efficiency of the operation and the environmental properties of the internal combustion engine can be improved. There are possibility to on-line supervision of fuel injection, feed forward of emission control, and feedback control of combustion process [17].

\section{Influence of EGR control at engine operating indexes}

\subsection{Control of EGR valve opening}

In order to understand the influence of the exhaust gas recirculation valve opening on the cylinder pressure, graphically the pressure waveforms at various openings of the exhaust gas recirculation valve for selected rotational speeds of 1000 and $1600 \mathrm{rpm}$ with a $190 \mathrm{Nm} \mathrm{load} \mathrm{was}$ presented.

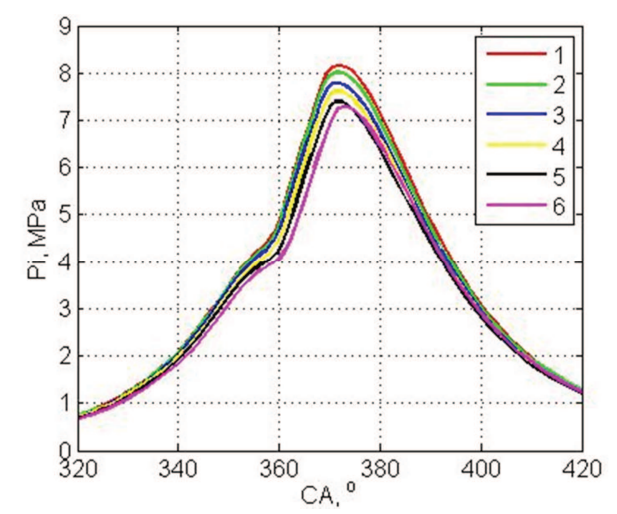

Fig. 4. In-cylinder pressure course at engine rotational speed $1000 \mathrm{rpm}$ and $190 \mathrm{Nm}$ load for different EGR opening level $(1-0 \%, 2-3 \%, 3-8 \%, 4-$ $15 \%, 5-50 \%, 6-100 \%)$

Of the wide range of degrees of opening of the EGR valve for comparison, 6 open positions corresponding to relative valve lifting of $0,3,8,15,50$ and $100 \%$ were se- lected. The in-cylinder pressure waveform are shown for 1000 rpm (Fig. 4) and 1600 rpm (Fig. 5) engine speed.

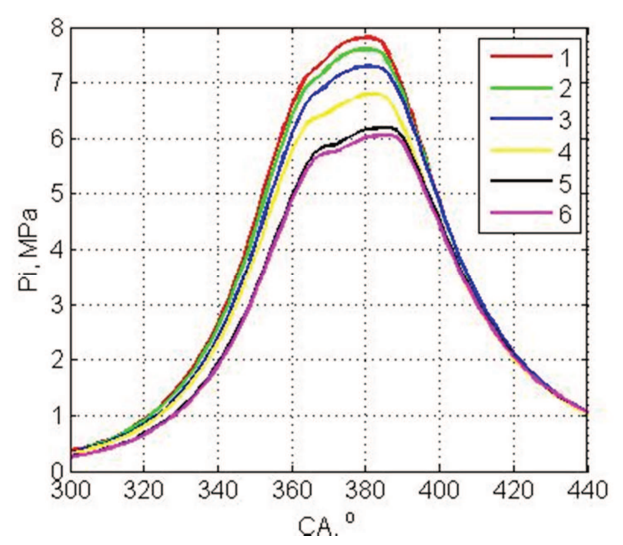

Fig. 5. In-cylinder pressure course at engine rotational speed $1600 \mathrm{rpm}$ at $190 \mathrm{Nm}$ load for different EGR opening level $(1-0 \%, 2-3 \%, 3-8 \%, 4-$ $15 \%, 5-50 \%, 6-100 \%)$

One of the basic parameters describing in-cylinder pressure is its maximum value. The effect of the EGR valve opening on the maximum cylinder pressure is shown in Fig. 6.

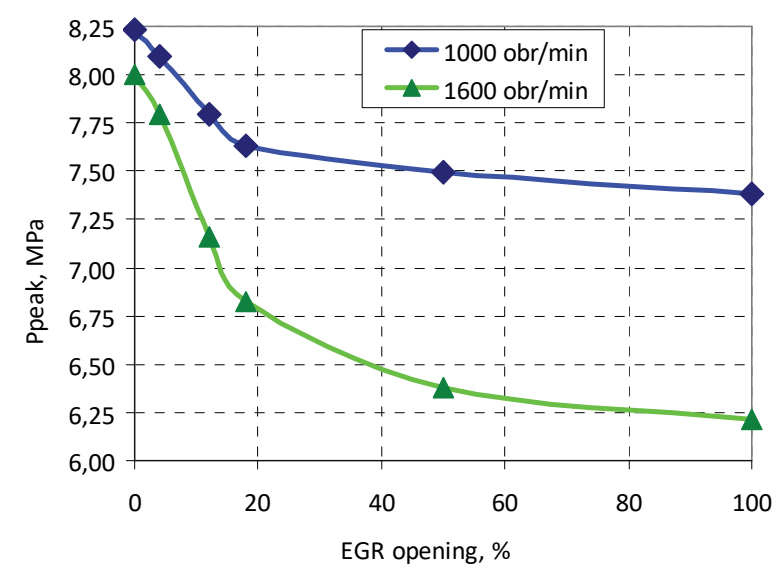

Fig. 6. Impact of EGR opening level at peak in-cylinder pressure

With the increase in the opening of the EGR valve, the maximum in-cylinder pressure drop can be observed. It is noteworthy that the greatest tendency of pressure drop is observed at the initial opening of the EGR valve, and at the same time this trend is more relevant for a higher rotational speed, which is accompanied by greater differences between the exhaust gas pressure and the intake manifold pressure, leading to an increase in the exhaust gas recirculation rate. Increasing the degree of EGR valve opening increases the rate of exhaust gas recirculation entering the cylinder. As a result, this will affect the combustion process, which takes place with less oxygen due to the increased share of exhaust gases entering the cylinder. There is a change in the dynamics of the combustion process, which manifests itself in differentiated MFB curves describing the dynamics of heat release in the cylinder.

Differential pressure variations for selected engine operating conditions at constant speeds of 1000 and $1600 \mathrm{rpm}$ and $190 \mathrm{Nm}$ load for various EGR valve opening stages are shown in Fig. 7 and Fig. 8. 
As the differential pressure waveform analysis shows, the highest values are noticeable for the closed EGR valve, ie. without external recirculation. Maximum pressure values are: 4.774 MPa closed for full EGR valve (EGR 0\%) and fully open (EGR 100\%) 4.327 MPa respectively (Fig. 7) and with rotational speed of $1600 \mathrm{rpm}$ and load of 190 $\mathrm{Nm}$, the maximum differential pressure is between 5.213 $\mathrm{MPa}$ for the closed EGR valve (EGR 0\%) and 4,007 $\mathrm{MPa}$ for the fully open valve (EGR 100\%) (Fig.8).

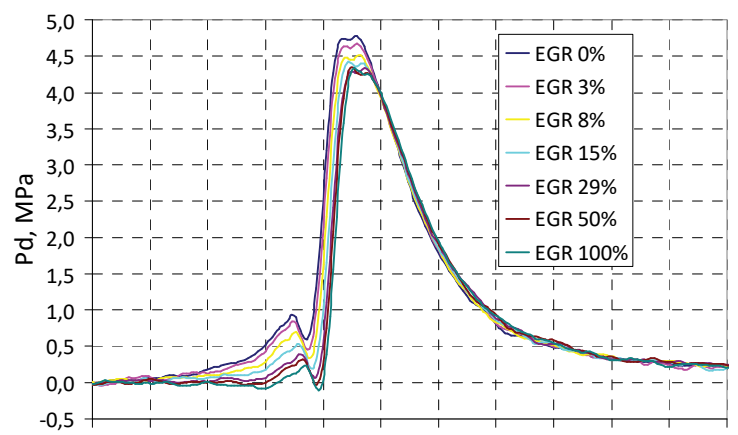

$\begin{array}{llllllllllll}280 & 300 & 320 & 340 & 360 & 380 & 400 & 420 & 440 & 460 & 480 & 500\end{array}$ CA, deg

Fig. 7. Differential pressure at different EGR valve opening level (1000 rpm, $190 \mathrm{Nm}$ )

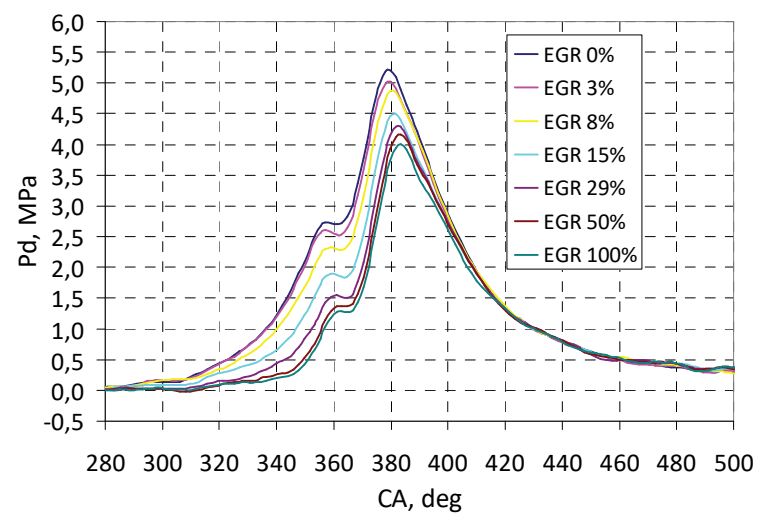

Fig. 8. Differential pressure at different EGR valve opening level (1600 rpm, $190 \mathrm{Nm}$ )

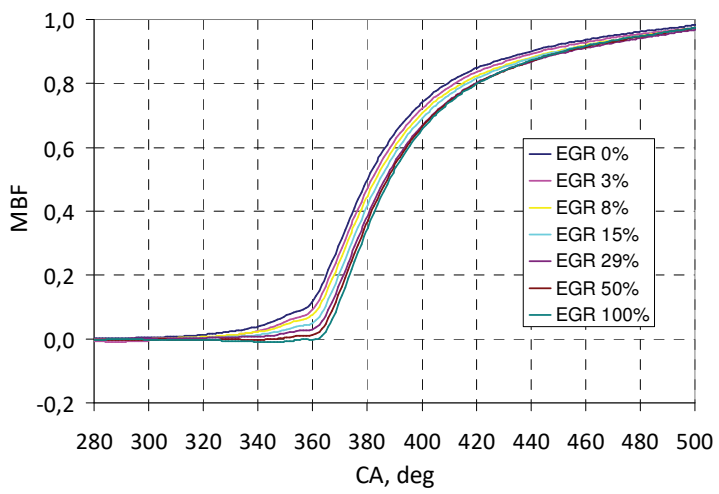

Fig. 9. Mass Fraction Burning course at different EGR valve opening level (1000 rpm, $190 \mathrm{Nm}$ )

It can be noted that for a rotational speed of $1600 \mathrm{rpm}$, the variation in both maximum pressure and waveforms is significantly higher than with a rotational speed of 1000 rpm. This demonstrates the greater extent of the effect of exhaust gas recirculation with the same EGR valve settings. As the next index the heat dissipation patterns MFB were plotted for the same engine operating conditions (Fig. 9 $1000 \mathrm{rpm}$, Fig. $10-1600 \mathrm{rpm}$. Also in this case, the influence of the EGR valve opening degree (exhaust gas recirculation rate) on the process of heat release in the cylinder was noticeable. Analysis of this graphs (Figs 9, 10) shows that dynamics releases heat in the case of high levels of exhaust gas recirculation is low in the first period of burning process, but intensifies as the combustion process progresses. Dynamics of heat release can be represented by the MFB values of $5 \%, 10 \%, 50 \%$ and $90 \%$ of the heat released during the combustion process, respectively mean as MFB $5 \%$, MFB $10 \%$, MFB 50\%, MFB90\%. The graphs (Figs 11 , $12,13,14)$ show the dependence of specific MFB values from the crankshaft angle for both engine speeds.

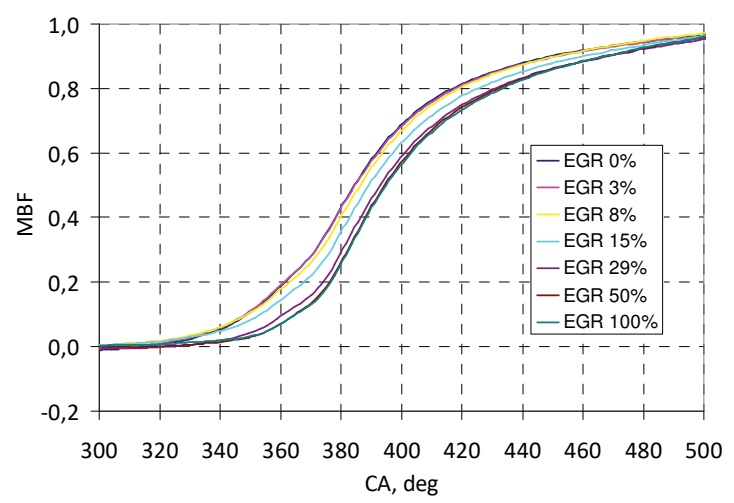

Fig. 10. Mass Fraction Burning course at different EGR valve opening level (1600 rpm, $190 \mathrm{Nm})$

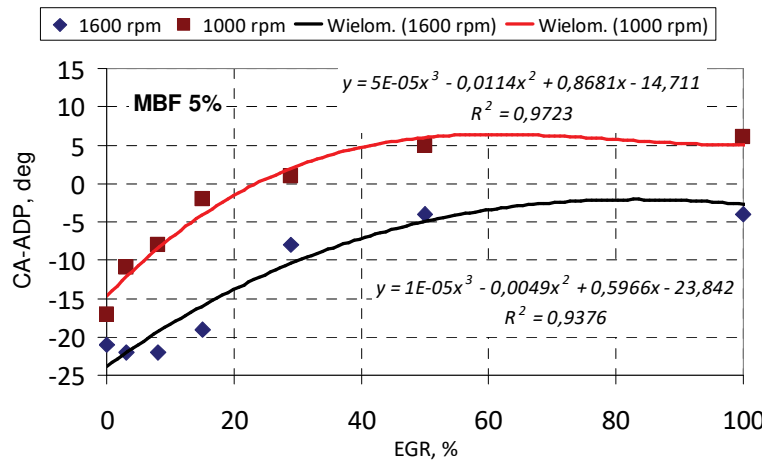

Fig. 11. Impact of EGR opening at MBF 5\% value (190 Nm load)

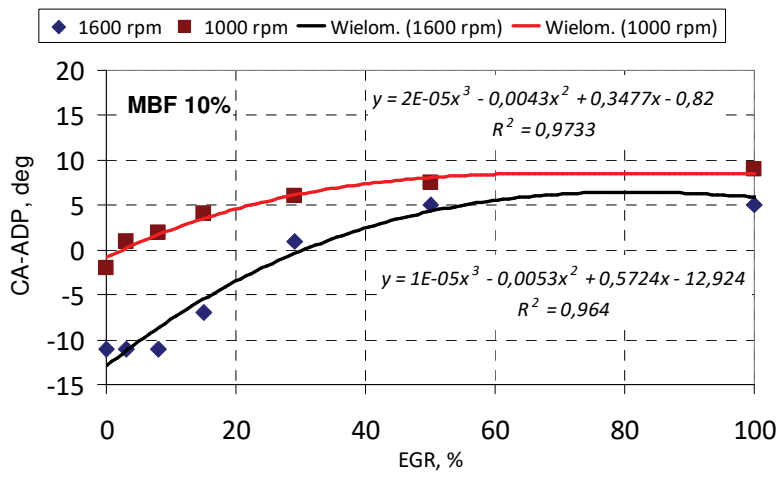

Fig. 12. Impact of EGR opening at MBF $10 \%$ value (190 Nm load) 


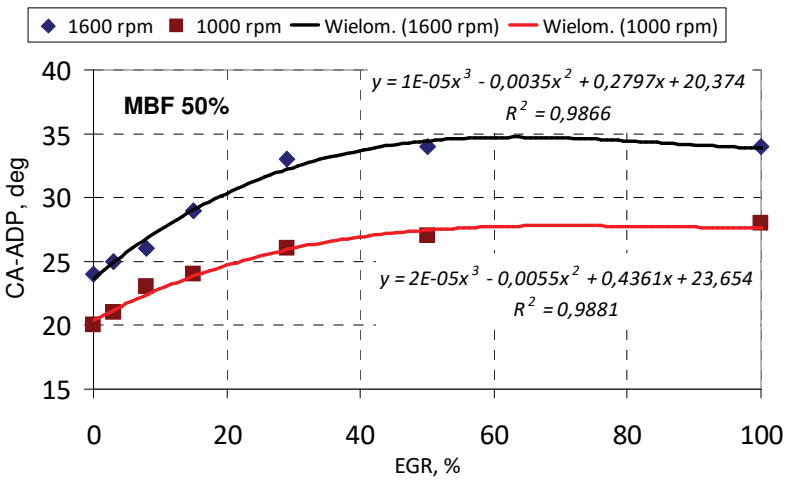

Fig. 13. Impact of EGR opening at MBF 50\% value (190 Nm load)

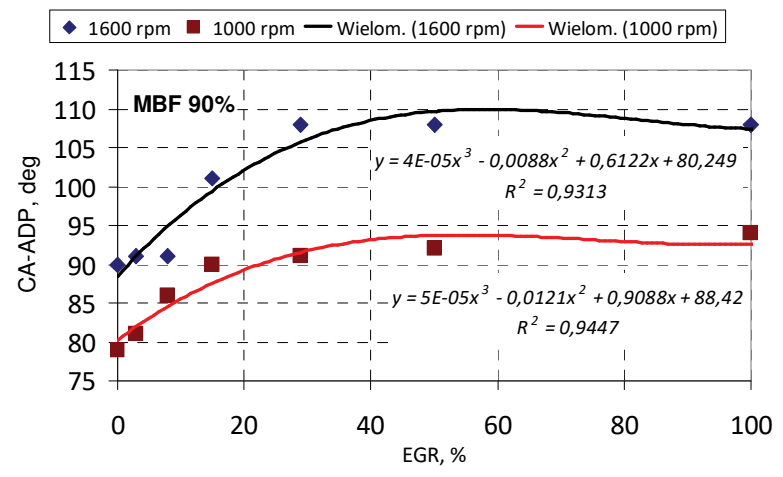

Fig. 14. Impact of EGR opening at MBF $90 \%$ value $190 \mathrm{Nm}$ load)

Release of $5 \%$ or $10 \%$ of heat for both tested engine speed in case of significant opening of the EGR valve occurs much later, that is about $20 \mathrm{CA}$ degrees later than in the absence of external exhaust gas recirculation. In turn, obtaining $50 \%$ of the MFB value is shifted by about $7-10$ CA degrees, and for $90 \%$ MFB respectively $15-18$ CA degrees. Duration to generate heat between $5 \%$ and $90 \%$ (Fig. 15) was also analyzed. Significant volume of exhaust gas returned to the cylinder does not significantly affect the duration of the value between MFB5\% and MFB $90 \%$.

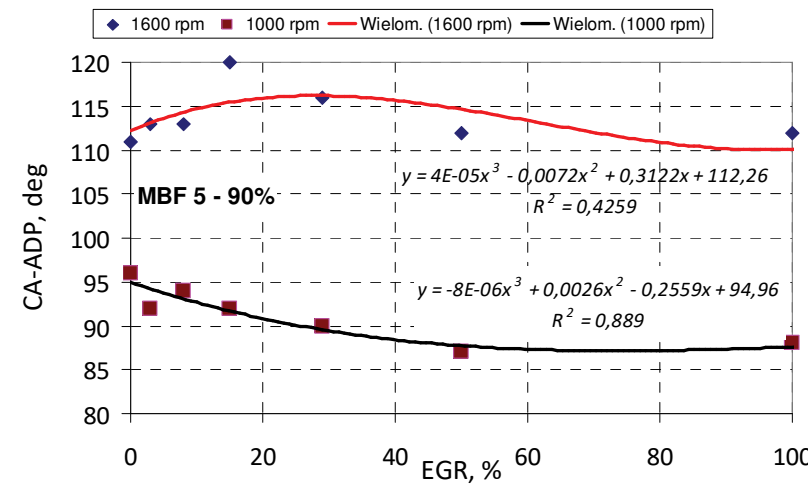

Fig. 15. Impact of EGR opening at duration of MBF 5\% - $90 \%$ value

In order to determine the effect of the EGR valve opening on the ecological properties of the test engine, the $\mathrm{NO}_{x}$ concentration and PM in the exhaust gas were analyzed. Figures 16 and 17 illustrate the effect of the opening of the EGR valve on $\mathrm{NO}_{\mathrm{x}}$ and $\mathrm{PM}$ concentrations at exhaust gases at 1000 and $1600 \mathrm{rpm}$. There are also $\mathrm{NO}_{\mathrm{x}}$ and PM concentrations expressed in absolute terms (Fig. 18).

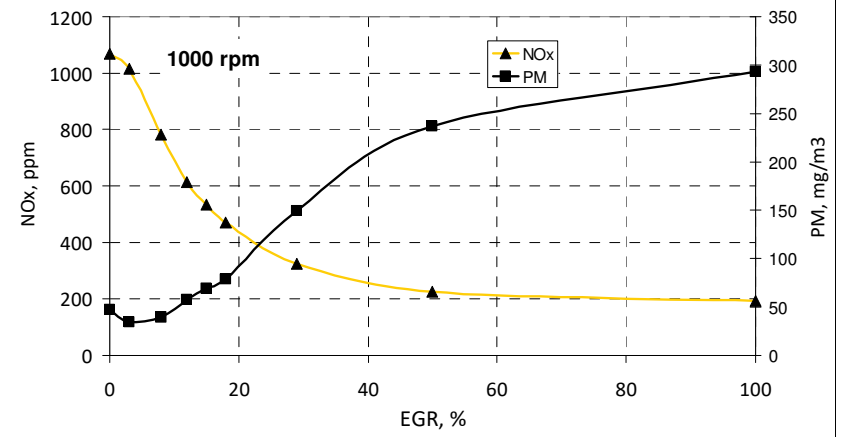

Fig. 16. Impact of EGR opening level at $\mathrm{NO}_{\mathrm{x}}$ and $\mathrm{PM}$ concentration (1000 $\mathrm{rpm}, 190 \mathrm{Nm}$ )

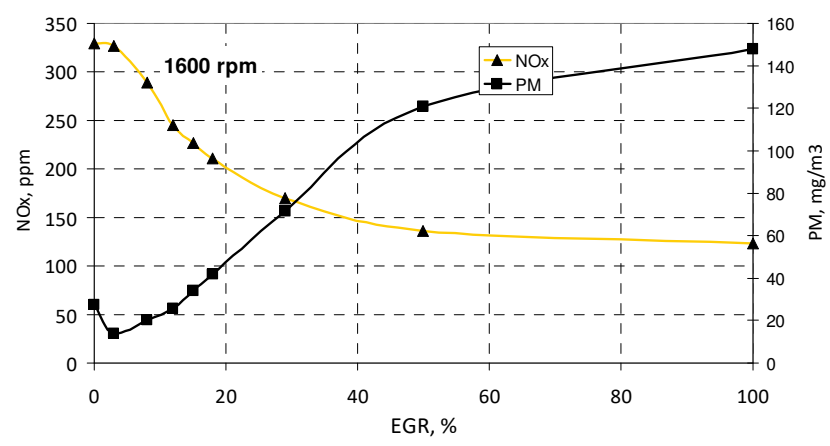

Fig. 17. Impact of EGR opening level at $\mathrm{NO}_{\mathrm{x}}$ and $\mathrm{PM}$ concentration (1600 rpm, $190 \mathrm{Nm}$ )

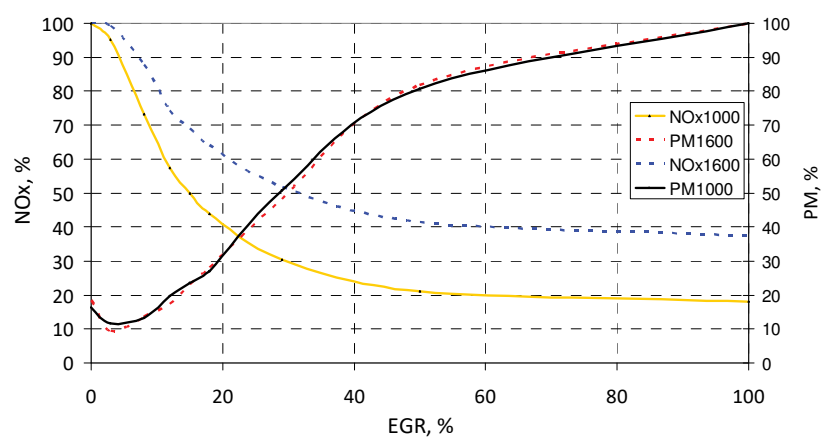

Fig. 18. Impact of EGR opening level at relative $\mathrm{NO}_{\mathrm{x}}$ and $\mathrm{PM}$ concentration at $190 \mathrm{Nm}$ load

The analysis shows the dependence of $\mathrm{NO}_{\mathrm{x}}$ and $\mathrm{PM}$ concentration in the exhaust gases according to the EGR valve opening degree. Limiting emissions of one of the tested substances by controlling the EGR valve is associated with an increase in the emissions of the other substance. The PM relative emission curves for different engine speeds overlap, and for $\mathrm{NO}_{\mathrm{x}}$ the curves are similar in shape, but the curve for higher rotational speeds is higher.

\subsection{Modified advanced EGR cooling system}

Finding the possibility of simultaneous reduction of both $\mathrm{NO}_{\mathrm{x}}$ and $\mathrm{PM}$ emissions through exhaust gas recirculation, requires advanced control of the system, but at the same time a search for methods to influence temperature of the exhaust gas. One of the goals of the survey is to determine the effect of intensive exhaust cooling on both thermodynamic and ecological indicators. The modified cooling system of recirculated exhaust gas was characterized by a high cooling efficiency. This system is based on two heat 
exchangers: the first gas-gas type and the second gas-liquid type. Increased cooling intensity was achieved by keeping the coolant temperature by about $50 \mathrm{~K}$ lower than in the standard recirculated exhaust cooling system. Comparison of differential pressure for standard and advanced cooling systems is presented for selected engine operating points in Figs 19-21. The results of the study were compared by individual waveforms with fully open EGR valve (EGR $100 \%)$.

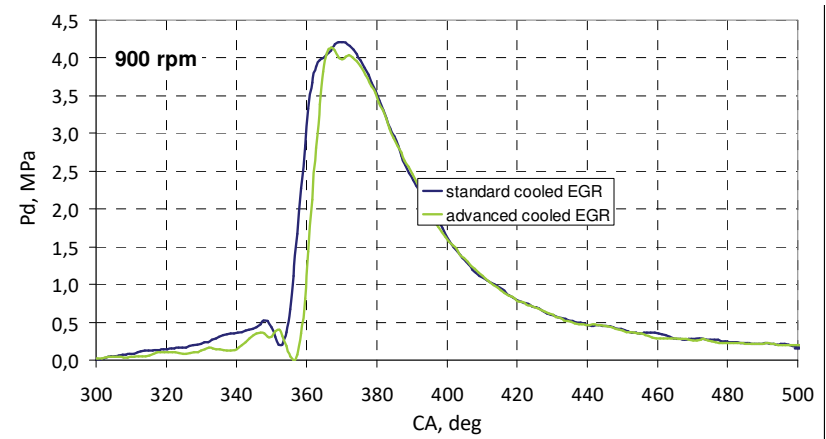

Fig. 19. Impact of EGR cooling system at differential pressure Pd (engine rotational speed: $900 \mathrm{rpm}, 190 \mathrm{Nm}$ load)

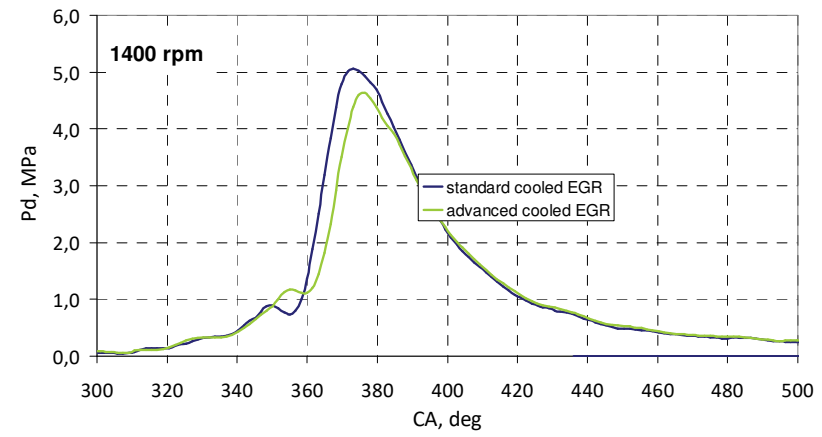

Fig. 20. Impact of EGR cooling system at differential pressure Pd (engine rotational speed: $1400 \mathrm{rpm}, 190 \mathrm{Nm}$ load)

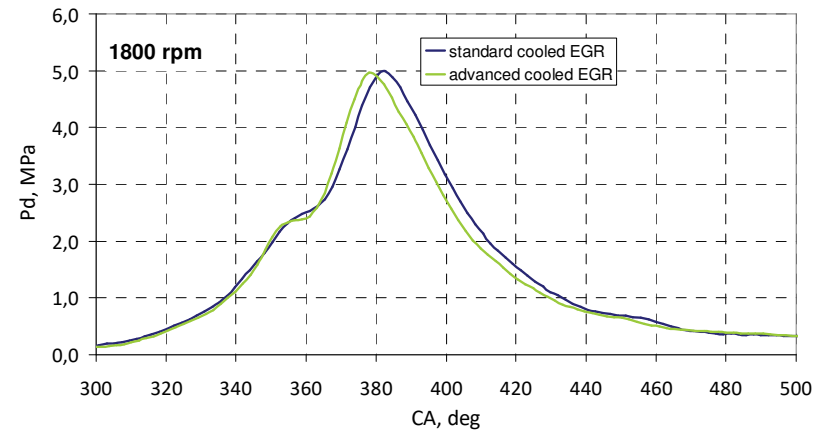

Fig. 21. Impact of EGR cooling system at differential pressure Pd (engine rotational speed:1800 rpm, $190 \mathrm{Nm}$ load)

Analysis of selected waveforms shows that the use of intensive exhaust cooling system with a fully open EGR valve significantly influences the pressure in the cylinder, which results in a reduction in differential pressure. At the same time, the waveform offset for the advanced cooling system is noticeable. The intensive cooling of the recirculated exhaust gases reduces the maximum in-cylinder pressure resulting in a decrease in maximum differential pres- sure from 4.126 to $4.136 \mathrm{MPa}$ for $900 \mathrm{rpm}, 5.070$ to 4.637 $\mathrm{MPa}$ for $1400 \mathrm{rpm}$ and symbolically from 4.989 to 4.966 MPa for $1800 \mathrm{rpm}$.

The differences in the differential pressure waveforms has effect on the changes in the heat release dynamics shown in the form of the MBF curves (Figs 22-24). It is noticeable to grow the intensity of heat release especially during the first period of combustion process.

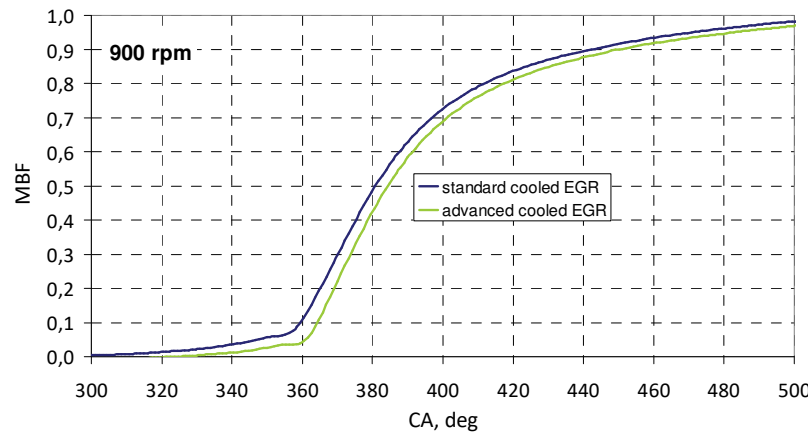

Fig. 22. Impact of EGR cooling system at MBF specific values (engine rotational speed: $900 \mathrm{rpm}, 190 \mathrm{Nm}$ load)

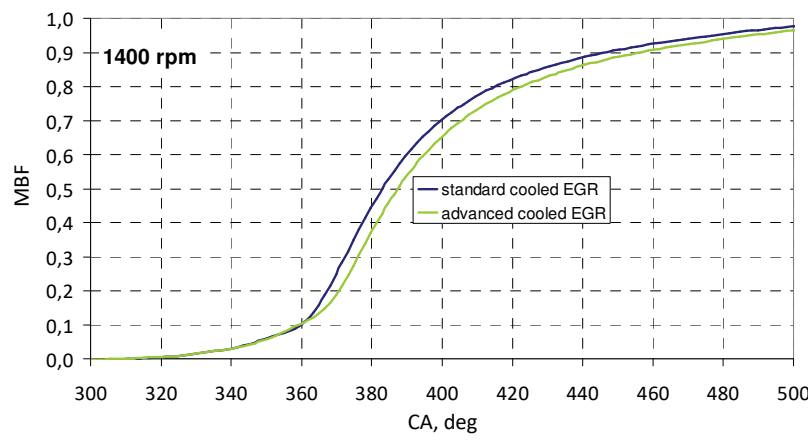

Fig. 23. Impact of EGR cooling system at MBF specific values (engine rotational speed: $1400 \mathrm{rpm}, 190 \mathrm{Nm}$ load)

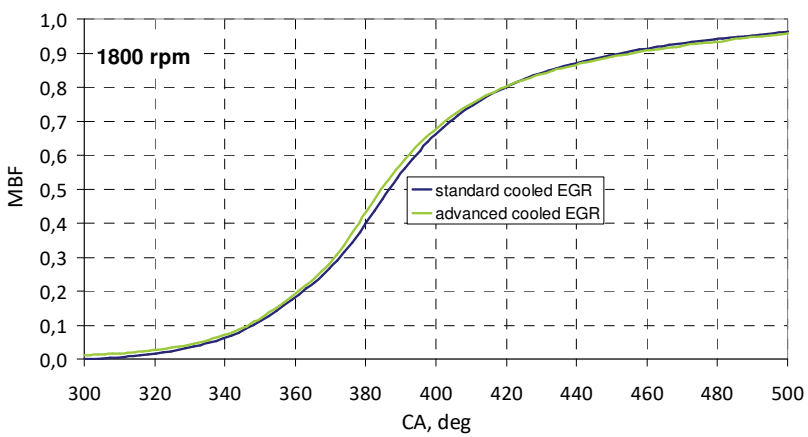

Fig. 24. Impact of EGR cooling system at MBF specific values (engine rotational speed: $1800 \mathrm{rpm}, 190 \mathrm{Nm}$ load)

This is most noticeable for the low engine rotational speeds, and the increase in this speed decreases the effect of the cooling intensity on the MBF curve.

More detailed analysis of the heat release dynamics in terms of the crankshaft angles (calculated relative to the crankshaft position corresponding to the piston position of the 1 st cylinder at the upper dead center point - CA-AFD) corresponding to the specific MBF values, ie, respectively, $5 \%, 10 \%, 50 \%$ and $90 \%$ is presented on Fig. 25-27. The 
differences are visible first for the lowest rotational speed of $900 \mathrm{rpm}$. There is a general trend towards greater heat release dynamics for advanced cooling systems especially in the first phase of the combustion process. Achieving a $5 \%$ or $10 \% \mathrm{MBF}$ value, is recorded from 19 to 0 degrees crank angle with a tendency to decrease this value for higher rotational speeds. Achieving a $50 \% \mathrm{MBF}$ value is usually a few degrees of CA later than with a standard cooling system. At the end of the combustion process, heat release dynamic slows down, resulting in achieving of MBF90\% of about 3 to 10 degrees CA later than the standard cooling system. There is also a tendency to observe lower values of CA-AFD corresponding to higher rotational engine speeds.

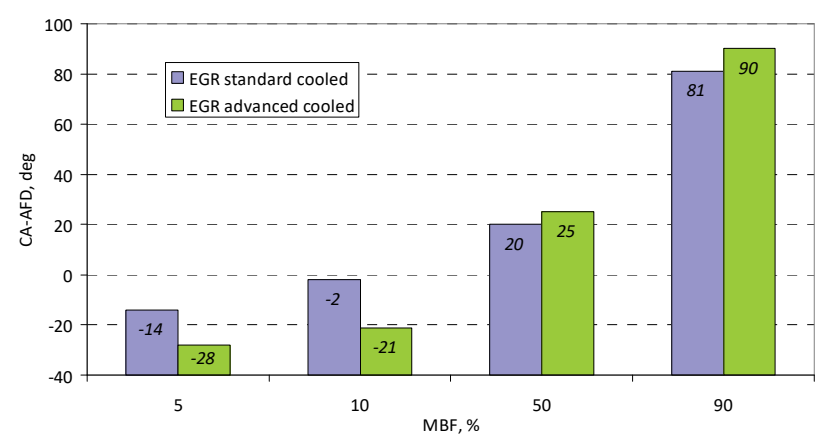

Fig. 25. Impact of EGR cooling system at CA - AFD of MBF specific value (engine rotational speed: $900 \mathrm{rpm}$, load: $190 \mathrm{Nm}$ load)

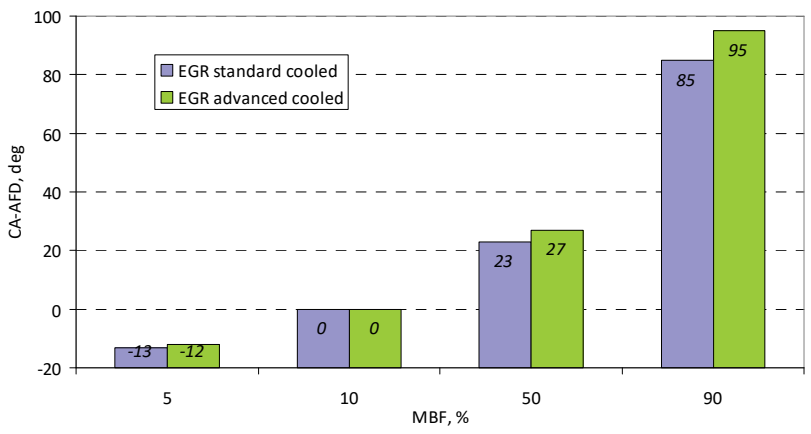

Fig. 26. Impact of EGR cooling system at CA -AFD of MBF specific value (engine rotational speed: $1400 \mathrm{rpm}$, load: $190 \mathrm{Nm}$ load)

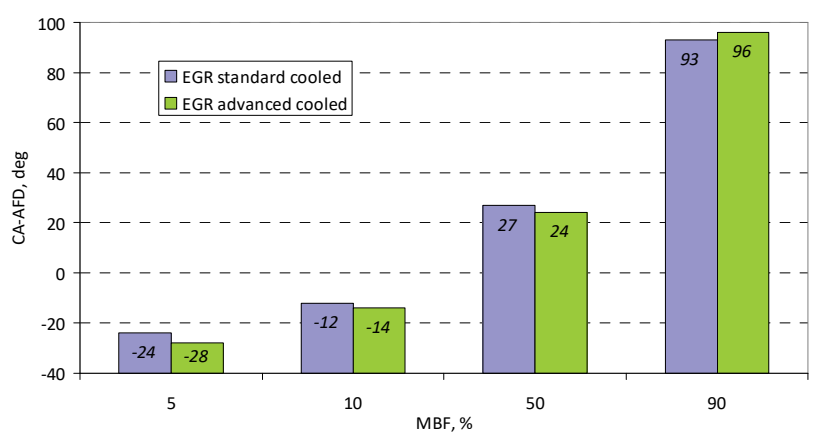

Fig. 27. Impact of EGR cooling system at CA -AFD of MBF specific value (engine rotational speed: $1800 \mathrm{rpm}$, load: $190 \mathrm{Nm}$ load)

It is very important to determine the influence of application an advanced EGR system characterized by intense exhaust gas cooling on the exhaust gases concentration of $\mathrm{NO}_{\mathrm{x}}$ and PM. Results of studies of such ecological properties are presented graphically in Figs 28-29. The recorded compara- tive curves of $\mathrm{NO}_{\mathrm{x}}$ and $\mathrm{PM}$ concentrations in the exhaust gas corresponding to the different recirculated exhaust gas cooling levels show possibilities for simultaneous reduction of emissions of the two concerned substances.

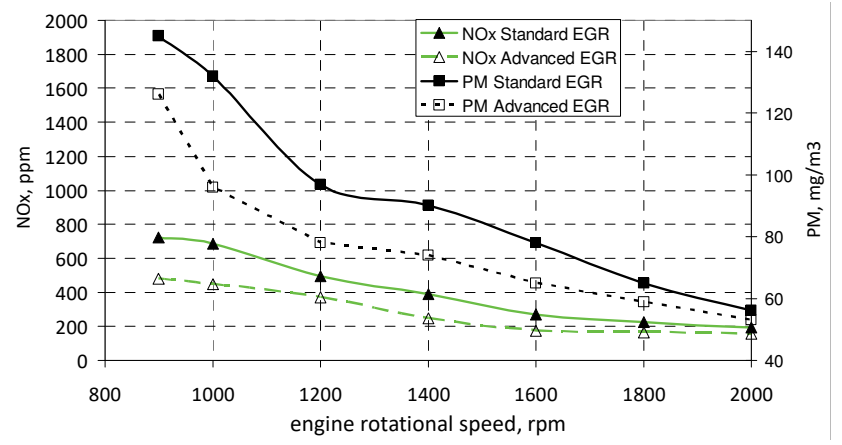

Fig. 28. Comparison of EGR cooling systems and $\mathrm{NO}_{\mathrm{x}}$ and PM concentration at exhaust gasses

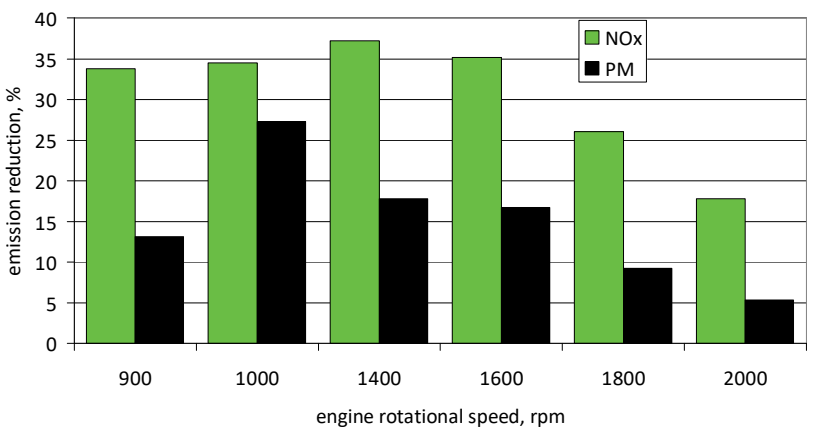

Fig. 29. Possibilities to emission reduction of $\mathrm{NO}_{\mathrm{x}}$ and $\mathrm{PM}$ thru advanced exhaust gas cooling system

Reduction of emissions compared to the standard exhaust cooling system is possible from 15 to over $30 \%$ with $\mathrm{NO}_{\mathrm{x}}$, and at the same time the emission of PM can reduced at a range from 5 to almost $30 \%$.

\section{Conclusions}

The study confirmed that controlling the EGR valve opening rate directly affecting the exhaust gas recirculation rate has a significant effect on the cylinder pressure. As a consequence, it results in changes in both thermodynamic and ecological engine properties. The studies have confirmed the significant effect of controlling the EGR valve opening rate on the differential pressure, obtaining the MFB specific values determining the method of heat release during combustion. Increasing the proportion of exhaust gas in the cylinder results in a reduction in maximum combustion pressure without reducing the torque available on the engine crankshaft. At the same time, the dynamics of heat release changes. The results of the studies also confirmed the correlation between the concentration of $\mathrm{NO}_{\mathrm{x}}$ and PM in the exhaust gases. Increase in the opening of the ERG valve rate, affect of $\mathrm{NO}_{\mathrm{x}}$ emissions reduction, but this results in a simultaneous increase in PM emissions. Controlling the degree of exhaust gas recirculation (through opening of the EGR valve rate) requires a compromise between the emission of these substances and consideration of the degree of extinction (emission reduction potential) of aftertreatment emission reduction systems. It has also been 
shown that advanced recirculation exhaust gas cooling systems with significant cooling intensity can achieve significant and also simultaneous reduction of both $\mathrm{NO}_{\mathrm{x}}$ and
PM concentrations in exhaust gases. Emissions reductions with advanced EGR systems can exceed $30 \%$ at selected engine operating points.

\section{Nomenclature}

CI compression ignition

CA crank angle

CA-AFD crank angle after center deadpoint

EGR exhaust gas recirculation
MBF mass burning fraction/ mass burn fuel

$\mathrm{NO}_{\mathrm{x}}$ nitrogen oxides

PM particulate matter

\section{Bibliography}

[1] BEASLEY, M. et al. Reducing diesel emissions dispersion by coordinated combustion feedback control. SAE Technical Paper. 2006, 2006-01-0186.

[2] BIENIEK, A., MAMALA, J., GRABA, M., LECHOWICZ, A. Control of advanced EGR system at nonroad diesel engine. $16^{\text {th }}$ Asia Pacific Automotive Engineering Conference - APAC Chennai India, SAE India M2010066, 1-6.

[3] BIENIEK, A., GRABA, M., LECHOWICZ, A. Adaptive control of exhaust gas recirculation at nonroad vehicle diesel engine, Journal of Kones 2011, 18(4), 11-18.

[4] BIENIEK, A., GRABA, M., LECHOWICZ, A. Control of agricultural engine injection system in aspect of ecological property improvement. Combustion Engines. 2011, SC0192, 1-8.

[5] BIENIEK, A., MAMALA, J., GRABA, M. Analysis of combustion process at multiphase injection at nonroad diesel engine, Combustion Engines. 2011, 4, SC-190, 1-8.

[6] BIENIEK, A. Conception of cylinder pressure based Diesel injection control system. Journal of Kones. Powertrain and Transport. 2011, 18(3), 27-35.

[7] BIENIEK, A., MAMALA, J., GRABA, M. Możliwości wstępnego ograniczenia emisji $\mathrm{NO}_{\mathrm{x}}$ i PM silnika wysokoprężnego $\mathrm{w}$ aspekcie przyszłościowych norm emisji pojazdów pozadrogowych. Zeszyty Naukowe Instytutu Pojazdów. 2012, 1(87), 75-86.

[8] BIENIEK, A. Wewnątrzsilnikowe ograniczenie emisji substancji szkodliwych w silniku wyposażonym w układ EGR pojazdu pozadrogowego. Inżynieria Rolnicza. 2013, 2(143), 31-41.

[9] CIEŚLIK, W., BOROWSKI, P., PIELECHA, I. et al. Systemy recyrkulacji spalin we współczesnych konstrukcjach silnikowych. Logistyka. 2014, 3, 1118-1127.

[10] GRABA, M., BIENIEK, A., MAMALA, J., LECHOWICZ, A. Sterowanie adaptacyjne zaworu recyrkulacji spalin w silniku o zapłonie samoczynnym w aspekcie obniżenia emisji substancji szkodliwych. Inżynieria Rolnicza. 2011, 5(130), 73-80.

Andrzej Bieniek, DEng. - Faculty of Mechanical Engineering at Opole University of Technology.

e-mail:A.Bieniek@po.opole.pl

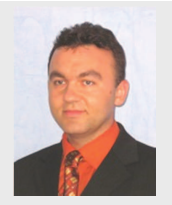

Jarosław Mamala, DSc., DEng. - Faculty of Mechanical Engineering at Opole University of Technology.

e-mail:J.Mamala@po.opole.pl
[11] GROMADKO, J., HONG, V., MILER, P. Applications of NRTC cycle to determine a different fuel consumption and harmful emissions caused by changes of engines technical conditions. Maintaince and Reliability. 2008, 4, 63-65.

[12] GUEZENNEC, Y., CANNOVA, M., GARZARELLA, M. et al. Control-oriented modeling for HCCI combustion and multi-cylinder HCCI experimental activities. The Ohio State University. Center for Automobile Research, Rapport 2005, $1-9$.

[13] HASEGAWA, M., SHIMASAKI, Y., et al. Study on ignition timing control for diesel engines using in-cylinder pressure sensor. SAE Technical Paper. 2006, 2006-01-0180.

[14] HEYWOOD, J.B. Internal combustion engine fundamentals. McGraw-Hill. 1988.

[15] KESSEL, J.-A., SCHMIDT, M., ISERMANN, R. Modelbasierte Motorsteuerung, Regelung und - Ueberwachung. MTZ. 1998, 59, 240-246.

[16] KOWALSKI, D., BIENIEK, A., BROL, S. Irregularity of rotational speed Diesel engine with modified fuel injection system. Journal of Kones, Powertrain and Transport. 2011, 18(4), 199-204.

[17] LEONHARD, S., MULLE,R N., ISERMANN, R. Methods for engine supervision and control based on cylinder pressure information. IEEE-ASME Transactions on Mechatronics. 1999, 3(4), 235-245.

[18] MENDERA, K.Z., SPYRA, A., SMERECKA, M. Mass fraction burned analysis. Journal of KONES Internal Combustion Engines. 2002, 3-4, 193-201.

[19] SOBIESZCZAŃSKI, M. et al. Wpływ parametrów regulacyjnych silnika ZS na zawartość składników toksycznych i zadymienie spalin. Nauka i technika. Eksploatacja $i$ niezawodność - Maintenace and Reliability. 2008, 3.

[20] SELLNAU, M., MATEKUNAS, F.A., BATTISTON, P. Cylinder-pressure-based engine control using pressure-ratiomanagement and low-cost non-intrusive cylinder pressure sensors. SAE Technical Paper. 2000, 2000-01-0932.

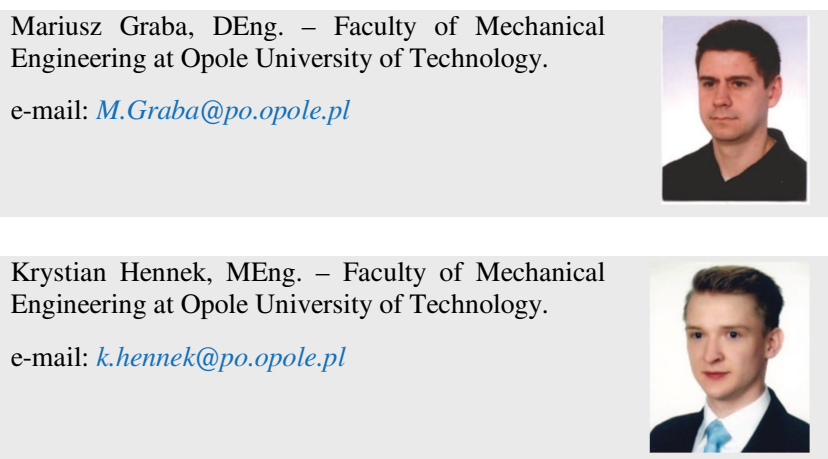

